\title{
Morphological Descriptions of Four Oligotrich Ciliates (Ciliophora: Oligotrichia) from Southern Coast of Korea
}

\author{
Eun Sun Lee ${ }^{1,2}$, Mann Kyoon Shin², Young-Ok Kim,* \\ ${ }^{1}$ Korea Ocean Research and Development Institute, Geoje 656-830, Korea \\ ${ }^{2}$ Department of Biological Science, University of Ulsan, Ulsan 680-749, Korea
}

\begin{abstract}
For the purpose of taxonomical description of marine oligotrich ciliates, water samples were collected from the southern coast of Korea (Masan Bay and Jangmok Bay). Ciliate cells were identified based on protargol impregnated specimens. As a result, four oligotrich ciliates were identified and redescribed: Rimostrombidium conicum (Kahl, 1932), Omegastrombidium kahli Song et al., 2009 and Spirotontonia turbinata (Song and Bradbury, 1998), and Spirotontonia grandis (Suzuki and Han, 2000). Of them, R. conicum, O. kahli, and S. turbinata are newly recorded and S. grandis is recorded for the second time in Korea, while the last one is redescribed to compare its variations according to locality. In addition, their abundances were analyzed and discussed the changes in accordance with water temperature and salinity.
\end{abstract}

Keywords: Rimostrombidium conicum, Omegastrombidium kahli, Spirotontonia grandis, Spirotontonia turbinata, oligotrich ciliates, taxonomy, Korean coastal water

\section{INTRODUCTION}

Ciliates have been recognized as important components in the marine microbial food webs and oligotrich ciliates usually occurred dominantly among the planktonic ciliate community (Froneman and Perissinotto, 1996; Quevedo and Anadón, 2000). According to Lynn (2008), the oligotrichs were divided into two subclasses; the Oligotrichia (oligotrichs sensu stricto) and the Choreotrichia, while the halteriids were affiliated with the stichotrichs. To date, about 1,490 species of oligotrichs (sensu lato) have been described worldwide but the validity is not confirmed. Of them, about 120 oligotrichids and 80 aloricate choreotrichids (not including tintinnids) have been recorded, only about $60 \%$ have been described, or redescribed using protargol staining method (Agatha, 2004a, 2004b, 2011; Agatha and Strüder-Kypke, 2007). Studies on marine planktonic ciliates have been carried out in Korea since 1980 's, only 4 oligotrichids and 10 aloricate choreotrichids have been reported (Table 1) (Suzuki and Han, 2000; Jeong et al., 2004; Moon et al., 2004; Kim et al., 2005, 2008, 2010b; Ma and Choi, 2005; Lee et al., 2006).

The ecological roles of Korean oligotrichs (especially, lori-

(c) This is an Open Access article distributed under the terms of the Creative Commons Attribution Non-Commercial License (http://creativecommons.org/ licenses/by-nc/3.0/) which permits unrestricted non-commercial use, distribution, and reproduction in any medium, provided the original work is properly cited. cate tintinnids) have been investigated in many studies (Yoo and Park, 2001; Kim and Lee, 2003; Yang and Choi, 2003; Moon et al., 2004; Kim et al., 2007; Lee et al., 2007; Han and Lee, 2010; Lee and Kim, 2010). They are frequently collected and abundant in the surface layer of coastal water and easily identified due to their large size and conserved lorica (Yoo et al., 1988; Yoo and Kim, 1990). Aloricate oligotrichs are more abundant than loricate tintinnids in microzooplankton community (Vaqué et al., 1997; Ota and Taniguchi, 2003). However, most ecological studies do not include them because they are not easy to handle due to their limited taxonomic information, fragility and small size of body (Yoo and Park, 2001; Kim and Lee, 2003; Lee and Kim, 2010). The taxonomic information of these taxa in Korea is urgently needed to investigate other related studies. Therefore we describe here four aloricate oligotrichs with their abundance including water temperature and salinity.

\section{MATERIALS AND METHODS}

\section{Sample collection}

Ciliate samples were seasonally collected from Masan Bay

\section{*To whom correspondence should be addressed \\ Tel: 82-55-639-8520, Fax: 82-55-639-8509 \\ E-mail: yokim@kordi.re.kr}

Copyright $(\mathcal{C})$ The Korean Society of Systematic Zoology 
Table 1. Number, habitat and references of oligotrich ciliates (Oligotrichida and Choreotrichida not including tintinnids) described taxonomically in Korea

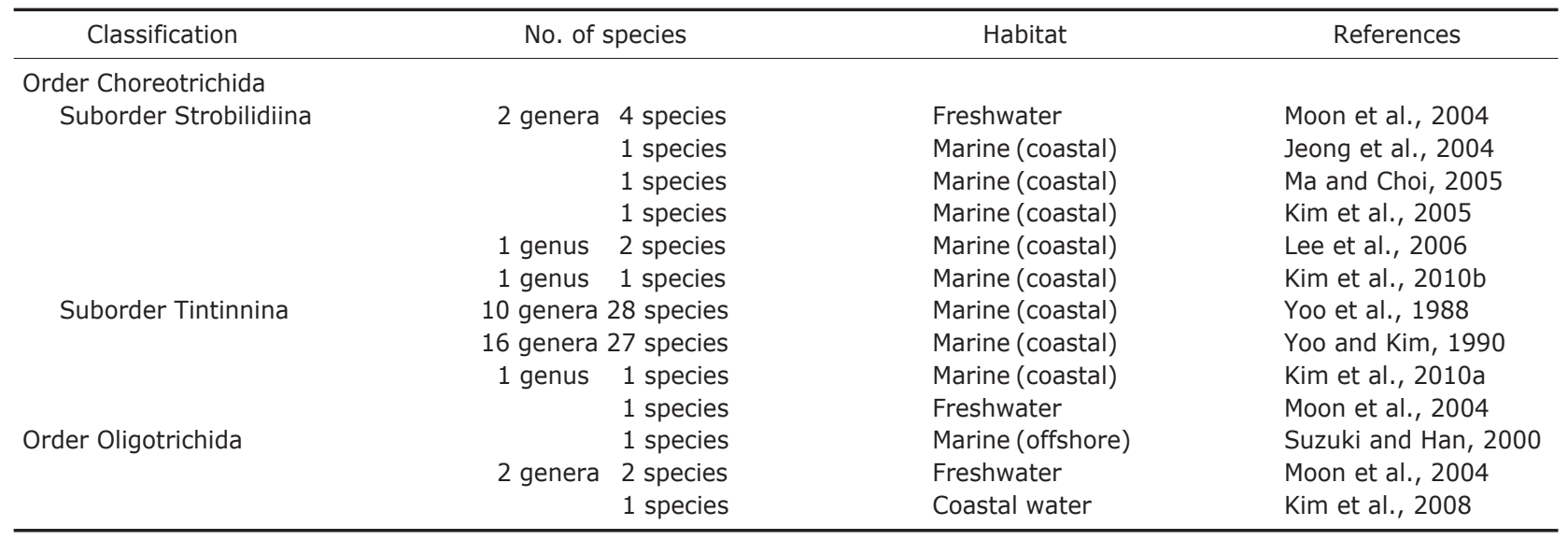

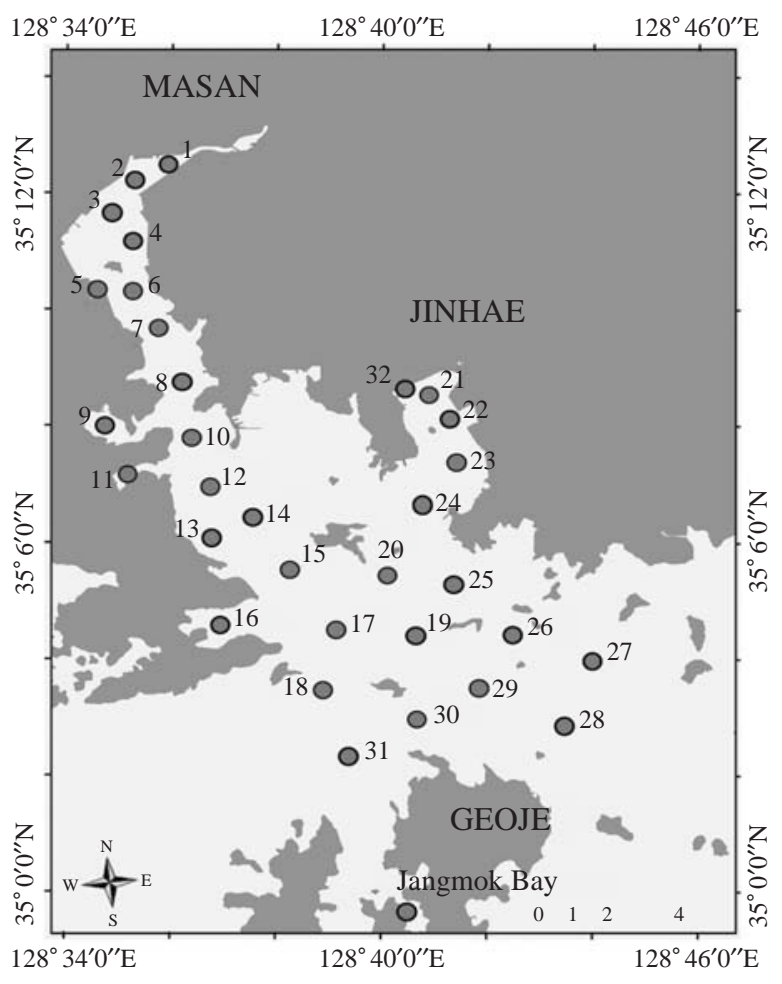

Fig. 1. Sampling sites located in the South Sea of Korea (M1M32 stations from Masan Bay and 1 station from Jangmok Bay).

using Van Dorn sampler at $0.5 \mathrm{~m}$ depth of selected sampling sites (32 sites) from April 2006 to November 2008 (February, May, August, and November). In Jangmok Bay, ciliates were sampled by vertical towing from $5 \mathrm{~m}$ depth to surface using a $20 \mu \mathrm{m}$ mesh plankton net $(30 \mathrm{~cm}$ diameter) in June 2009 (Fig. 1). Samples were fixed immediately by Bouin's solution (at final concentration $10 \%, \mathrm{v} / \mathrm{v}$ ) in which most of the ciliates were well preserved. Water temperature and salinity were measured in situ using a portable T-S meter (556 MPS; YSI, USA).

\section{Morphological investigations}

In order to observe the morphological characteristics of ciliate cells, the fixed cells were stained and mounted using the quantitative protargol staining and the modified Wilbert's method (Wilbert, 1975; Montagnes and Lynn, 1987; Foissner et al., 1999). Ciliate cells were identified and counted under $\times 400-1,000$ magnification using a light microscope (Zeiss Axioskop II, Goettingen, Germany).

\section{Terminology}

Terminology and classification for the ciliate taxonomy are according to Montagnes and Lynn (1991) and Agatha (2004a).

\section{RESULTS AND DISCUSSION}

Class Oligotrichea Bütschli, 1889

Subclass Oligotrichia Bütschli, 1889

1*Order Choreotrichida Small and Lynn, 1985

${ }^{2 *}$ Suborder Strobilidiina Jankowski, 1980

3*Family Strobilidiidae Kahl in Doflein and Reichenow, 1929

4*Genus Rimostrombidium Jankowski, 1978

${ }^{5 *}$ Rimostrombidium conicum (Kahl, 1932)

(Table 2, Fig. 2)

Strobilidium conicum Kahl, 1932: 506. 

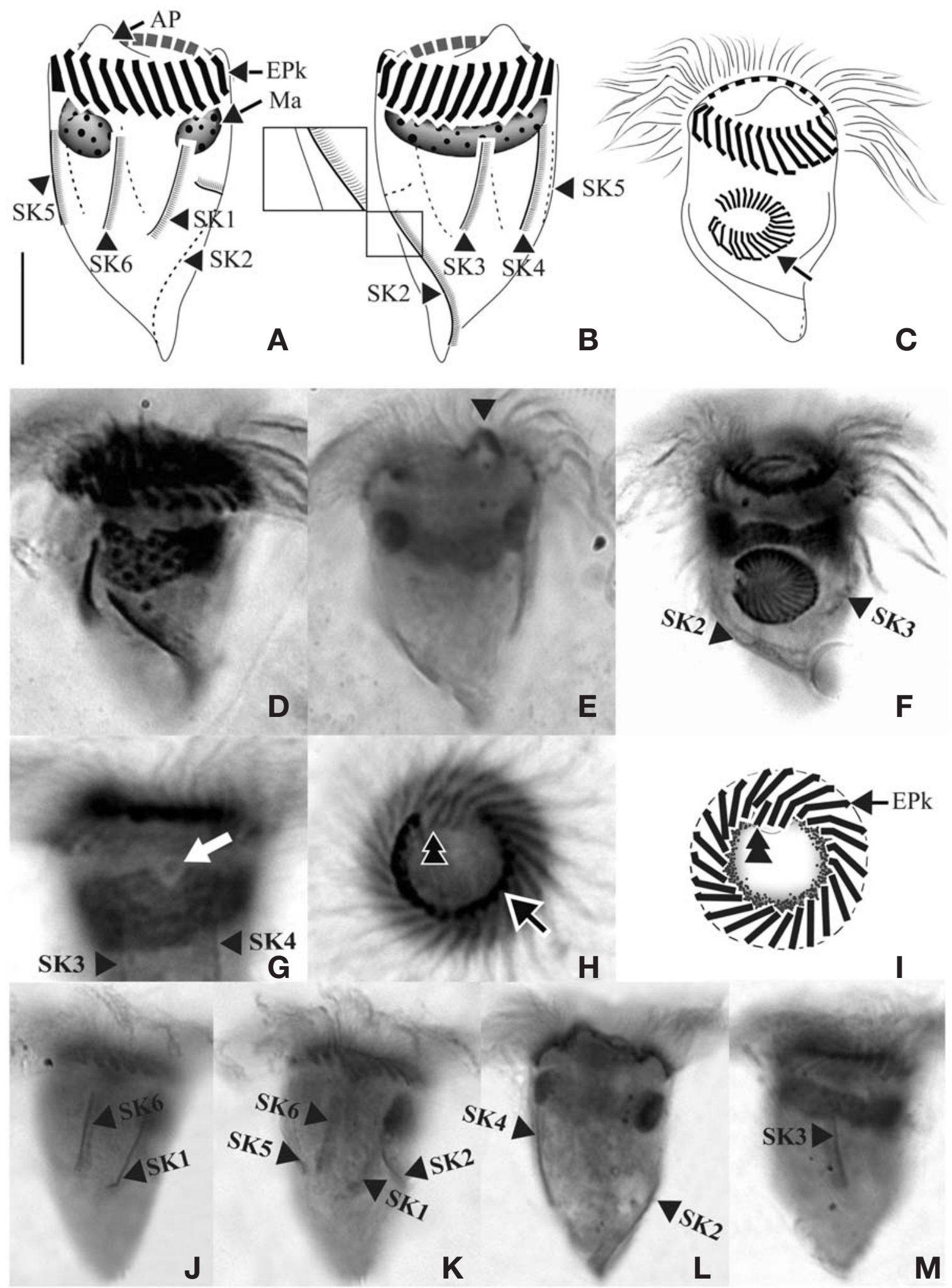

Fig. 2. Rimostrombidium conicum after protargol impregnation. $A$, Ventral view; B, Dorsal view; C, F, Oral primordium (OP) originating between SK2 and SK3 (arrow indicating OP in C); D, Left view; E, Black arrowhead indicating a conspicuous AP; G, White arrow indicating Mi; H, I, Apical view showing EPks, IPk and black circle (double arrowhead showing IPk in $\mathrm{H}$ and I, black arrow indicating black circle in $\mathrm{H})$; J-M, SK arrangement. AP, apical protuberance. Scale bar: $10 \mu \mathrm{m}$. 
Table 2. Morphometrical characterization of Rimostrombidium conicum (R.c.), Omegastrombidium kahli (O.k.), Spirotontonia turbinata (S.t.), and Spirotontonia grandis (S.g.)

\begin{tabular}{|c|c|c|c|c|c|c|c|c|}
\hline Characteristics & Species & Min & Max & Mean & SD & SE & $\mathrm{CV}$ & $\mathrm{N}$ \\
\hline \multirow[t]{4}{*}{ Cell length } & R.c. & 22.0 & 43.0 & 30.5 & 4.8 & 1.0 & 15.7 & 24 \\
\hline & O.k. & 43 & 82.0 & 68.2 & 10.5 & 2.5 & 15.4 & 17 \\
\hline & S.t. & 59.0 & 110.0 & 77.2 & 17.2 & 5.7 & 22.3 & 9 \\
\hline & S.g. & 87.0 & 157.5 & 107.5 & 16.5 & 3.4 & 15.4 & 23 \\
\hline \multirow[t]{4}{*}{ Cell width } & R.c. & 12.0 & 21.0 & 17.5 & 1.8 & 0.4 & 10.1 & 24 \\
\hline & O.k. & 28 & 45.0 & 36.5 & 4.6 & 1.1 & 12.5 & 17 \\
\hline & S.t. & 29.0 & 51.0 & 36.8 & 6.7 & 2.2 & 18.1 & 9 \\
\hline & S.g. & 32.0 & 52.0 & 41.2 & 4.9 & 1.0 & 11.9 & 23 \\
\hline \multirow[t]{4}{*}{ Cell length : width, ratio } & R.c. & 1.3 & 2.7 & 1.8 & 0.3 & 0.1 & 18.6 & 23 \\
\hline & O.k. & 1.3 & 2.2 & 1.9 & 0.2 & 0.1 & 12.7 & 17 \\
\hline & S.t. & 1.9 & 2.6 & 2.1 & 0.2 & 0.1 & 10.7 & 9 \\
\hline & S.g. & 1.7 & 3.7 & 2.6 & 0.4 & 0.1 & 16.2 & 23 \\
\hline \multirow[t]{2}{*}{ Anterior pole to buccal vertex, distance } & S.t. & 30.0 & 57.5 & 38.3 & 8.9 & 3.0 & 23.3 & 9 \\
\hline & S.g. & 37.0 & 103.5 & 54.6 & 12.7 & 2.6 & 23.2 & 23 \\
\hline \multirow[t]{2}{*}{ Cell length : anterior pole to buccal vertex, ratio } & S.t. & 1.7 & 2.5 & 2.0 & 0.3 & 0.1 & 12.5 & 9 \\
\hline & S.g. & 1.3 & 2.4 & 2.0 & 0.3 & 0.1 & 14.0 & 23 \\
\hline EPk, number & R.c. & 22 & 26 & 24 & 1.0 & 0.2 & 4.3 & 23 \\
\hline EPk, length & R.c. & 4.0 & 5.0 & 4.6 & 0.4 & 0.1 & 8.1 & 7 \\
\hline \multirow[t]{3}{*}{ AM, number } & o.k. & 44 & 58 & 51.7 & 4.3 & 1.6 & 8.3 & 7 \\
\hline & S.t. & 13 & 15 & 14 & 0.5 & 0.2 & 3.8 & 8 \\
\hline & S.g. & 13 & 15 & 14 & 0.6 & 0.1 & 4.3 & 22 \\
\hline \multirow[t]{2}{*}{ AM, length } & S.t. & 18.0 & 20.0 & 19.0 & 1.4 & 1.0 & 7.4 & 2 \\
\hline & S.g. & 12.0 & 20.0 & 18.0 & 3.0 & 1.1 & 16.7 & 7 \\
\hline \multirow[t]{3}{*}{ VM, number } & o.k. & 6 & 13 & 8.9 & 2.3 & 0.9 & 26.4 & 7 \\
\hline & S.t. & 15 & 20 & 17 & 2 & 1 & 10 & 9 \\
\hline & S.g. & 23 & 34 & 28 & 3.1 & 0.7 & 11.3 & 23 \\
\hline pTM, number & o.k. & 2 & 2 & 2 & 0.0 & 0.0 & 0.0 & 7 \\
\hline \multirow[t]{2}{*}{ GK, number of whorl } & S.t. & 2 & 3 & 2.4 & 0.4 & 0.1 & 16.0 & 9 \\
\hline & S.g. & 3 & 3 & 3 & 0.0 & 0.0 & 0.0 & 23 \\
\hline \multirow[t]{2}{*}{ Dikinetids of GK, number (per $10 \mu \mathrm{m}$ ) } & S.t. & 10 & 14 & 12 & 1.5 & 0.6 & 13.2 & 6 \\
\hline & S.g. & 14 & 19 & 15 & 1.5 & 0.4 & 9.8 & 14 \\
\hline \multirow[t]{2}{*}{ Probably fibers, number per $10 \mu \mathrm{m}$} & S.t. & 6 & 10 & 9 & 1.6 & 0.7 & 18.1 & 6 \\
\hline & S.g. & 5 & 9 & 7 & 1.5 & 0.5 & 21.3 & 11 \\
\hline SK 1, length & R.c. & 10.0 & 15.0 & 11.7 & 1.4 & 0.3 & 12.1 & 22 \\
\hline SK 2, length & R.c. & 19.0 & 28.0 & 21.5 & 2.8 & 1.0 & 12.9 & 8 \\
\hline SK 3, length & R.c. & 8.0 & 13.0 & 9.5 & 1.4 & 0.3 & 15.0 & 26 \\
\hline SK 4, length & R.c. & 9.0 & 18.0 & 12.4 & 2.3 & 0.5 & 18.4 & 24 \\
\hline SK 5, length & R.c. & 8.0 & 16.0 & 11.5 & 1.8 & 0.4 & 15.8 & 24 \\
\hline SK 6, length & R.c. & 9.0 & 15.0 & 10.9 & 1.6 & 0.3 & - & 23 \\
\hline \multirow[t]{3}{*}{ Ma, number } & o.k. & 35 & 62 & 45.1 & 8.1 & 2.9 & 17.9 & 8 \\
\hline & S.t. & 50 & 60 & 55 & 5.0 & 2.9 & 9.1 & 3 \\
\hline & S.g. & 37 & 84 & 65 & 14.0 & 3.2 & 21.5 & 19 \\
\hline \multirow[t]{3}{*}{ Ma, diameter } & o.k. & 2.0 & 5.5 & 3.3 & 1.0 & 0.3 & 30.9 & 9 \\
\hline & S.t. & 3.0 & 3.5 & 3.2 & 0.3 & 0.2 & 9.1 & 3 \\
\hline & S.g. & 3.0 & 4.0 & 3.4 & 0.4 & 0.1 & 12.9 & 19 \\
\hline Mi, diameter & R.c. & 1.5 & 2.0 & 1.8 & - & - & - & 2 \\
\hline
\end{tabular}

Data based on protargol impregnated specimens. Measurements in $\mu \mathrm{m}$.

Min, minimum; Max, maximum; Mean, arithmetic mean; SD, standard deviation; SE, standard error; CV, coefficient of variation; N, number of specimen.

Rimostrombidium conicum Petz and Foissner, 1992: 160; Agatha and Riedel-Lorjé, 1998: 14.
Diagnosis. Body asymmetrically conical shaped; cell size $22-43 \mu \mathrm{m}$ in length and $12-21 \mu \mathrm{m}$ in width after protargol preparation; 22-26 EPks; one separated IPk; 6 SKs, SK2 longer 


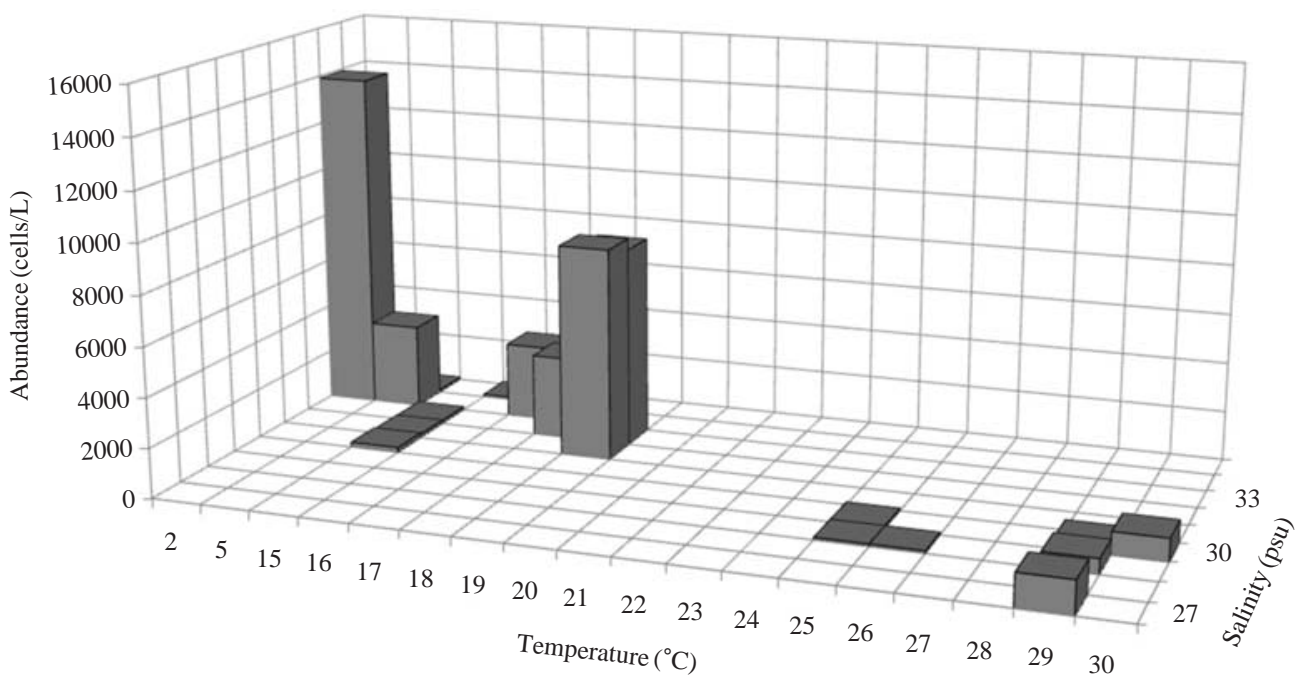

Fig. 3. Abundances of Rimostrombidium conicum at different temperatures $\left({ }^{\circ} \mathrm{C}\right)$ and salinities (psu) in Masan Bay.

than the other kineties, and spirally extending to posterior cell end, SK1, 3, 4, 5, and 6 not extending to posterior end and slightly curved or straight; one Ma C- or horseshoe-shaped and horizontally located underneath EPZ.

Morphological description of Korean population. Body asymmetrically conical shaped with conspicuous protuberance at anterior pole of cell, bluntly tapering in posterior region. Body size $22-43 \mu \mathrm{m}$ in length and $12-21 \mu \mathrm{m}$ in width (average $31 \times 18 \mu \mathrm{m}, \mathrm{n}=24$ ) after protargol impregnation (Fig. 2A, B, D, E).

EPZ closed and surrounding anterior end of cell, consisting of 22-26 polykinetids (average $24, \mathrm{n}=23$ ). Two elongated EPks extending into eccentric oral cavity. One IPk lying into oral cavity and separated from EPks. A black circle observed below anterior part of EPZ, having gap into oral cavity ("C" shaped position), probably fibres (Fig. 2H, I).

Six SKs composed of short cilia. Except for SK2, SKs not extending to posterior pole of cell and having similar lengths: SK1, $12 \mu \mathrm{m}$; SK3, $10 \mu \mathrm{m}$; SK4, $12 \mu \mathrm{m}$; SK5, $12 \mu \mathrm{m}$; and SK6, $11 \mu \mathrm{m}$ on average. SK2 longer than the other kineties (average $22 \mu \mathrm{m}$ in length, $\mathrm{n}=8$ ), slightly sinistrally spiraled and extended to posterior pole of cell. SK1 and SK6 less or not sinistrally curved than SK3-5 slightly dextrally curved or longitudinal (Fig. 2J-M).

Single Ma C- or horseshoe-shaped and contained numerous globular nucleoli, horizontally located underneath EPZ with ventrally opening. One ellipsoidal Mi positioned on dorsal side of Ma (Fig. 2G).

Oral primordium developing between SK2 and SK3 de novo (Fig. 2C, F).

Occurrence and ecological characteristics. Maximum abundance $(13,900$ cells/L) of this species was observed at M4 site in Masan Bay in February 2008, where water temperature of $2.13^{\circ} \mathrm{C}$ and salinity of 34.21 psu were recorded. This species showed highest abundance in cold water $\left(2-5^{\circ} \mathrm{C}\right)$ but also occurred at high temperatures $\left(\geq 15^{\circ} \mathrm{C}\right)$ in low abundances (100-8,600 cells/L) (Fig. 3).

Comparison with other populations. German population was collected from the brackish and coastal waters of the North Sea and with maximum abundance of 100,000 cells/L in August while the maximum abundance of Korean population occurred in February (about 13,900 cells/L) (Agatha and Riedel-Lorjé, 1998). The morphology of Korean population is similar to German population (e.g., cell size, shape, number of SKs and EPKs, shape, and location of Ma), except for the arrangement of somatic kineties. SK1 of German population is the longest (vs. SK2 the longest in Korean population). German population has dextrally spiral SK2 which does not reach a posterior pole (vs. SK2 extending to posterior pole in Korean population) (Agatha and Riedel-Lorjé, 1998).

$1 *$ Order Oligotrichida Bütschli, 1889

2*Family Strombidiidae Fauré-Fremiet, 1970

${ }^{3 *}$ Genus Omegastrombidium Agatha, 2004

4*Omegastrombidium kahli Song et al., 2009

(Table 2, Fig. 4)

Omegastrombidium kahli Song et al., 2009: 336-337.

Korean name: ${ }^{1 *}$ 개구환소모충목, ${ }^{2 *}$ 민소모충과, ${ }^{3 *}$ 오메 가열소모충속, ${ }^{4 *}$ 다핵오메 가열소모충 

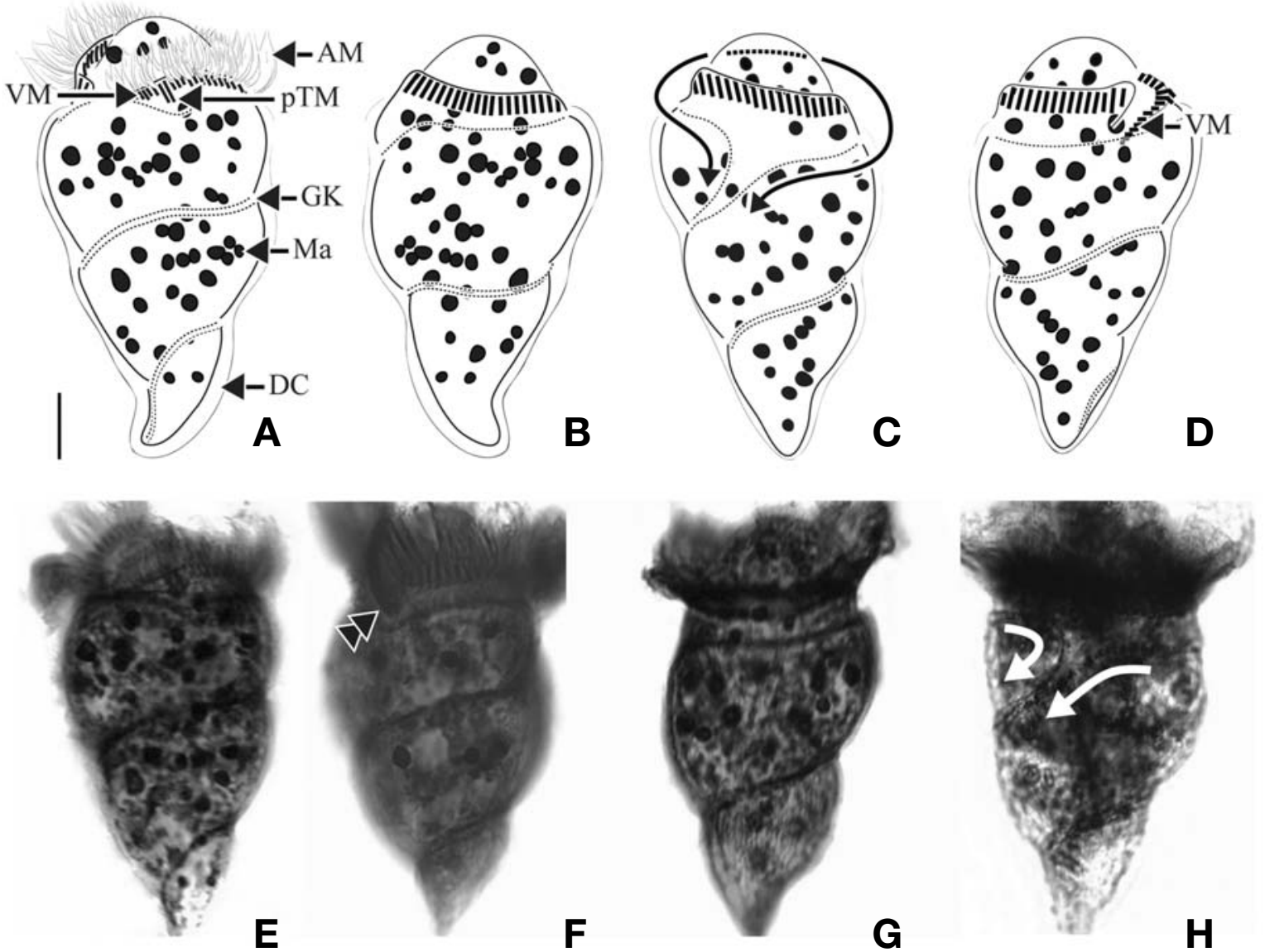

Fig. 4. Omegastrombidium kahli after protargol impregnation. $A, E, F$, Ventral view (double arrowhead in $F$ indicating pTM); $B$, G, Dorsal view; C, H, Left view (white arrows in $\mathrm{H}$ indicating direction of GK); D, Right view. DC, distended cell surface. Scale bar: $10 \mu \mathrm{m}$.

Diagnosis. Body obconical with screw-like appearance; cell size 43-82 $\mu \mathrm{m}$ in length and $28-45 \mu \mathrm{m}$ in width after protargol preparation; 44-58 AM, 6-13 VM, and 2 pTM; dextrally spiral GK, performing about 2 whorls; 35-62 ellipsoidal Ma, about $2-5.5 \mu \mathrm{m}$ in diameter.

Morphological description of Korean population. Body dextrally screwed cone- or turban shell-shaped with conspicuous apical protrusion (AP) at anterior pole. Cell size 43-82 $\mu \mathrm{m}$ in length, and $28-45 \mu \mathrm{m}$ in width (average $68 \times 37 \mu \mathrm{m}$, $\mathrm{n}=17$ ) after protargol impregnation. Transparent distended cell surface (DC) covered from GK to posterior end of cell (Fig. 4A-D).

Oral polykinetids surrounding anterior pole with ventral opening, divided into AM and VM. Approximate 44-58 AM (average 52, n=7) and 6-13 VM (average 9, n=7). Two pTM positioned between $\mathrm{AM}$ and $\mathrm{VM}$ and obviously longer than AM and VM (Fig. 4A, F).

GK originated at anterior part of body, both ends facing on left side of anterior part and turning approximately 1.5-2 whorls (with dextrally spiraling) and then terminating at pos-

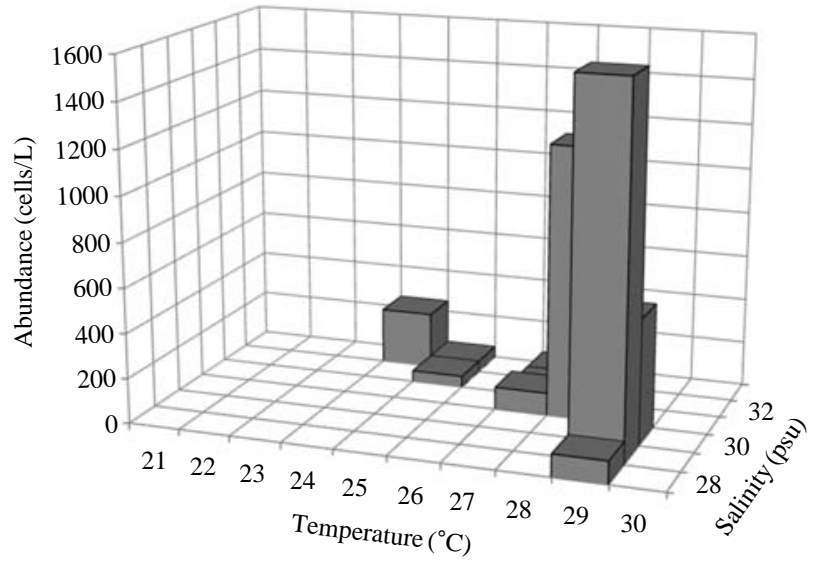

Fig. 5. Abundances of Omegastrombidium kahli at different temperatures $\left({ }^{\circ} \mathrm{C}\right)$ and salinities (psu) in Masan Bay.

terior end on right lateral side (Fig. 4C, D). GK on ventral side obliquely extended to right side while GK on dorsal side positioned horizontally (Fig. 4A, B). No ventral kinety found. 
About 35-62 (average 45, $\mathrm{n}=8$ ) ellipsoidal Ma $(2-5.5 \mu \mathrm{m}$ in diameter), scattered throughout cell.

Occurence and ecological characteristics. Maximum abundance (ca. 1,600 cells/L) of this species was observed at M4 site in August, 2007 where water temperature of $29.13^{\circ} \mathrm{C}$ and salinity of 28.69 psu were recorded respectively. This species was strictly found at high temperatures $\left(24-29^{\circ} \mathrm{C}\right)$ period (Fig. 5).

Comparison with Chinese population. Omegastrombidium kahli was recently recorded by Song et al. (2009). Korean population is the second record. Two populations are similar in morphology: marine species collected from coastal water in salinity about $30 \mathrm{psu}$; cell shape; the number of AM and $\mathrm{VM}$; the presence and number of pTM, and the shape and number of Ma. However, cell size of Korean population is smaller than Chinese population $(43-82 \times 28-45 \mu \mathrm{m}$ of Korean population vs. $60-80 \times 40-50 \mu \mathrm{m}$ of Chinese population). Number of Ma of Korean population is larger than that of Chinese population (35-62 vs. 20-30). Chinese population is vague about the appearance of an AP but Korean population shows a conspicuous protrusion at anterior end of the cell after protargol impregnation.
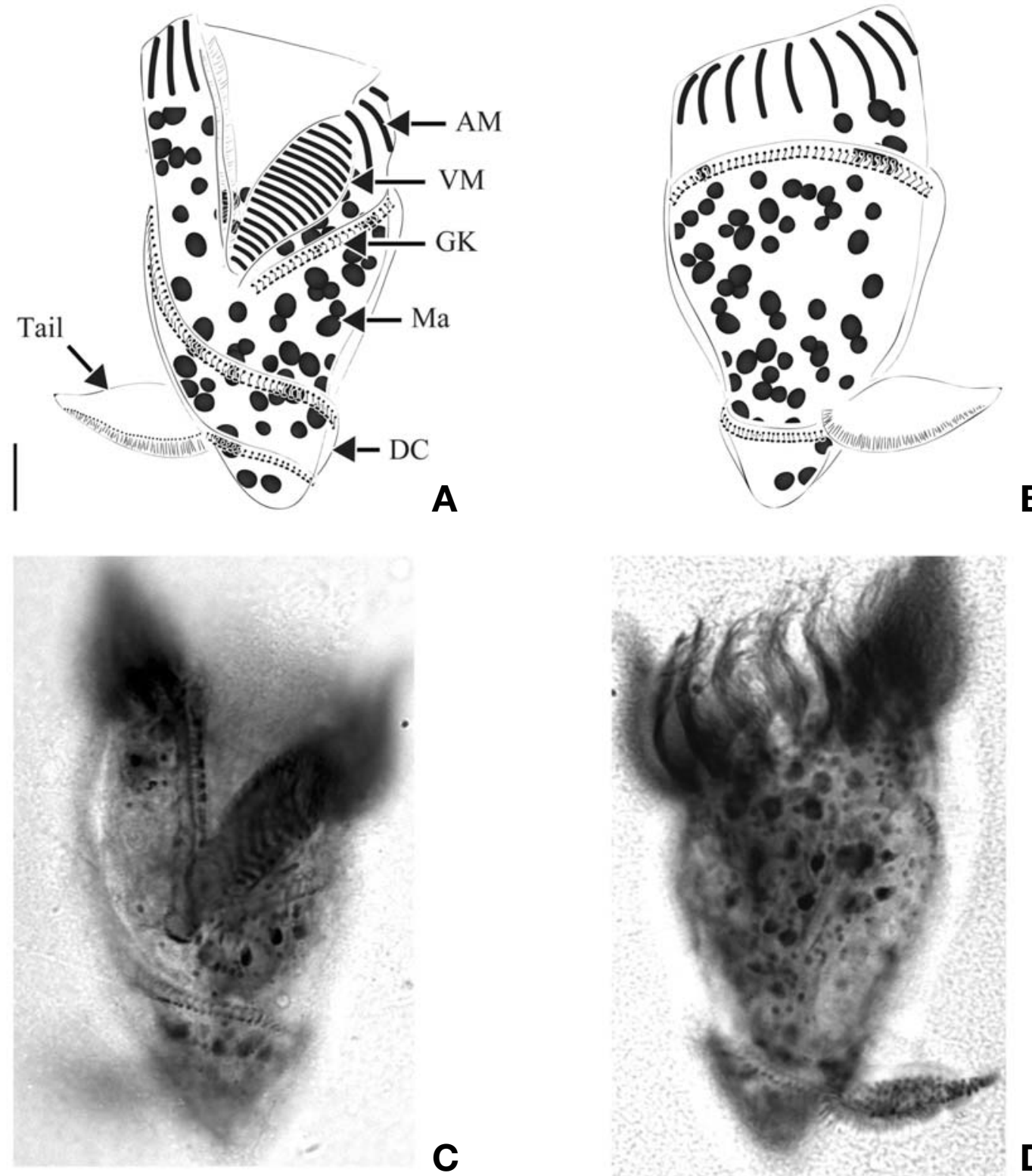

C

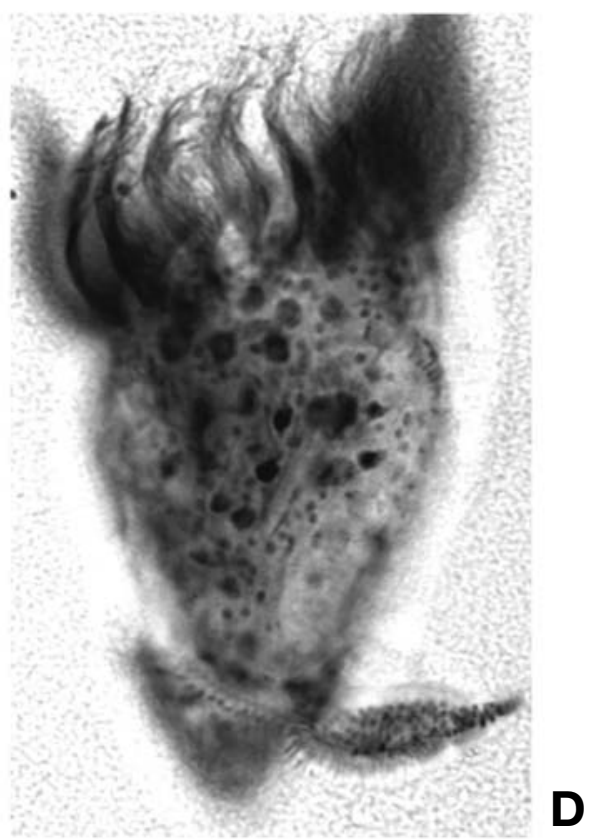

Fig. 6. Spirotontonia turbinata after protargol impregnation. A, C, Ventral view; B, D, Dorsal view. DC, distended cell surface. Scale bar: $10 \mu \mathrm{m}$. 
1*Family Tontoniidae Agatha, 2004

${ }^{2 *}$ Genus Spirotontonia Agatha, 2004

${ }^{3 *}$ Spirotontonia turbinata (Song and Bradbury, 1998)

(Table 2, Fig. 6)

Spirotontonia turbinata Song et al., 2009: 334.

Diagnosis. Body inverted triangle-shaped with tail on dorsal side of posterior cell end; body size, $59-110 \mu \mathrm{m}$ in length and 29-51 $\mu \mathrm{m}$ in width after protargol impregnation; 13-15 AM and 15-20 VM; sinistrally spiral GK (about 2.5 whorls); no VK; ellipsoidal Ma, size 3-3.5 $\mu \mathrm{m}$ in diameter, and 50-60 in number.

Morphological description of Korean population. Body obconical to inverted triangle with bluntly pointed posterior end, slightly leftward inclined anterior portion of body. Body size, $59-110 \mu \mathrm{m}$ in length and $29-51 \mu \mathrm{m}$ in width (average $77 \times 37 \mu \mathrm{m}, \mathrm{n}=9$ ). Tail located above the second whorl of GK on dorsal side, easily detached from body during process of handling or staining. A kinety consisting of densely spaced basal bodies with fibers on front of tail. Body covered with transparent DC between whorls of GK (Fig. 6A-D).

Buccal cavity open on ventral side, extending slightly to right and terminating approximately $1 / 2$ of way down cell. AM and VM positioned like question-marked ("?") on ventral side. About 13-15 AM (average 14, $n=8$ ). VM extended along left side of buccal cavity and consisting of 15-20 membranelles (average 17, $\mathrm{n}=9$ ). A row of EM lying on inner wall of buccal lip on right inner side of oral cavity, consisting of densely arranged monokinetids (Fig. 6A, C).

Sinistrally spiral GK orientating on left side of buccal cavity, extending to left lateral side along posterior margin of VK then spirally turning down to posterior of body with about 2 whorls (average of GK per $10 \mu \mathrm{m}, 12$ ). "L" shaped fibres located above GK and arranged along GK (average of F per $10 \mu \mathrm{m}, 9)$. No VK detected.

Ellipsoidal Ma scattered in whole of body, size 3-3.5 $\mu \mathrm{m}$ in diameter (average $3 \mu \mathrm{m}$ in diameter, $\mathrm{n}=3$ ), 50-60 in number (average 55, $\mathrm{n}=3$ ).

Occurence and ecological characteristics. This species were collected in November 2006 and in August 2008 from Masan Bay (water temperature of $15-23.27^{\circ} \mathrm{C}$ and salinity of 30.30-32.6 psu) and in June 2009 from Jangmok Bay (water temperature of $17.45-23.27^{\circ} \mathrm{C}$ and salinity of $30.30-31.51$ psu). Maximum abundance of 150 cells/L showed at M20 and M30 sites in August 2006 where water temperature of $15^{\circ} \mathrm{C}$ and salinity of 32.6 psu were recorded respectively (Fig. 7).

Comparison with other populations. Spirotontonia turbi-

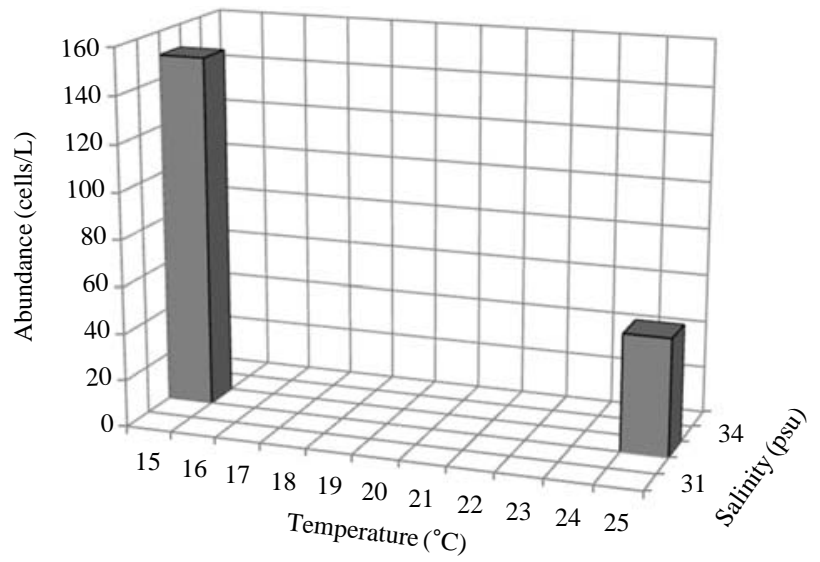

Fig. 7. Abundances of Spirotontonia turbinata at different temperatures $\left({ }^{\circ} \mathrm{C}\right)$ and salinities (psu) in Masan Bay.

nata was initially reported from coastal of north China (Song and Bradbury, 1998). Unfortunately, water temperature and salinity were not recorded for the occurrence. Compared with Chinese population, Korean population has similar cell size and number of AM. However, there are some morphological differences between these two populations: the number of Ma (Korean population, 50-60 vs. Chinese population, 28-40), the number of VM (15-20 vs. 13-17), the number of GK whorls ( 2.5 whorls vs. 1.5 whorls), and the ratio of cell length to cell width (2.1 vs. 1.38).

${ }^{4 *}$ Spirotontonia grandis (Suzuki and Han, 2000)

(Table 2, Fig. 8)

Tontonia grandis Suzuki and Han, 2000: 989-994. Spirotontonia grandis Agatha, 2004a: 298.

Diagnosis. Body obconical with screw-like appearance; size $87-157.5 \mu \mathrm{m}$ in length and $32-52 \mu \mathrm{m}$ in width after protargol impregnation; a conspicuously apical collar (AC) located at anterior pole; tail on dorsal side; 13-15 AM and 23-34 VM; sinistrally spiral GK of three whorls, oriented below buccal area and terminated at posterior end of dorsal side; no VK; 37-84 ellipsoidal Ma, about 3-4 $\mu \mathrm{m}$ in diameter.

Morphological description of Korean population. Body screwed barrel in shape with $\mathrm{AC}$ at anterior pole, posterior of cell bluntly pointed. AC region truncate- or dome-shaped. Cell size $87-157.5 \mu \mathrm{m}$ in length and $32-52 \mu \mathrm{m}$ in width (average $108 \times 41 \mu \mathrm{m}, \mathrm{n}=23$ ) after protargol impregnation. Tail broad leaf shaped, located above the second whorl of GK on dorsal side, easily detached from body during handling in staining process. A short kinety positioned across front view of tail, consisting of densely spaced basal bodies and fibers

Korean name: ${ }^{1 *}$ 꼬리소모충과, ${ }^{2 *}$ 나선체 꼬리소모충속, ${ }^{3 *}$ 원추나선체 꼬리소모충, ${ }^{4 *}$ 큰나선체 꼬리소모충 
(Fig. 8F). Back view of tail wrinkled. Transparent DC covered between whorls of GK (Fig. 8A, B). Cortical platelets observed in several specimens, having elliptical shape and covering on DC surface (Fig. 8G).

Buccal cavity open, extending obliquely to right and terminating about $1 / 2$ of way down cell. AM surrounding AC region, consisting of 13 to $15 \mathrm{AM}$ (average $14, \mathrm{n}=22$ ). VM extending along left side of buccal cavity, consisting of 2334 membranelles (average 28, $n=23$ ). A row of EM lying on inner wall of buccal lip on right side of buccal cavity, consisting of monokinetids.

Sinistrally spiral GK, with a total of three whorls, located below posterior part of buccal cavity, extending to left lateral side along posterior margin of $\mathrm{VK}$ and turning around dorsal side horizontally, then sharply going down to proximal part on ventral side and then spirally going down two whorls, finally terminating at posterior end of dorsal side. F (probably fibers) parallel arrangement above GK; "L"-shaped in
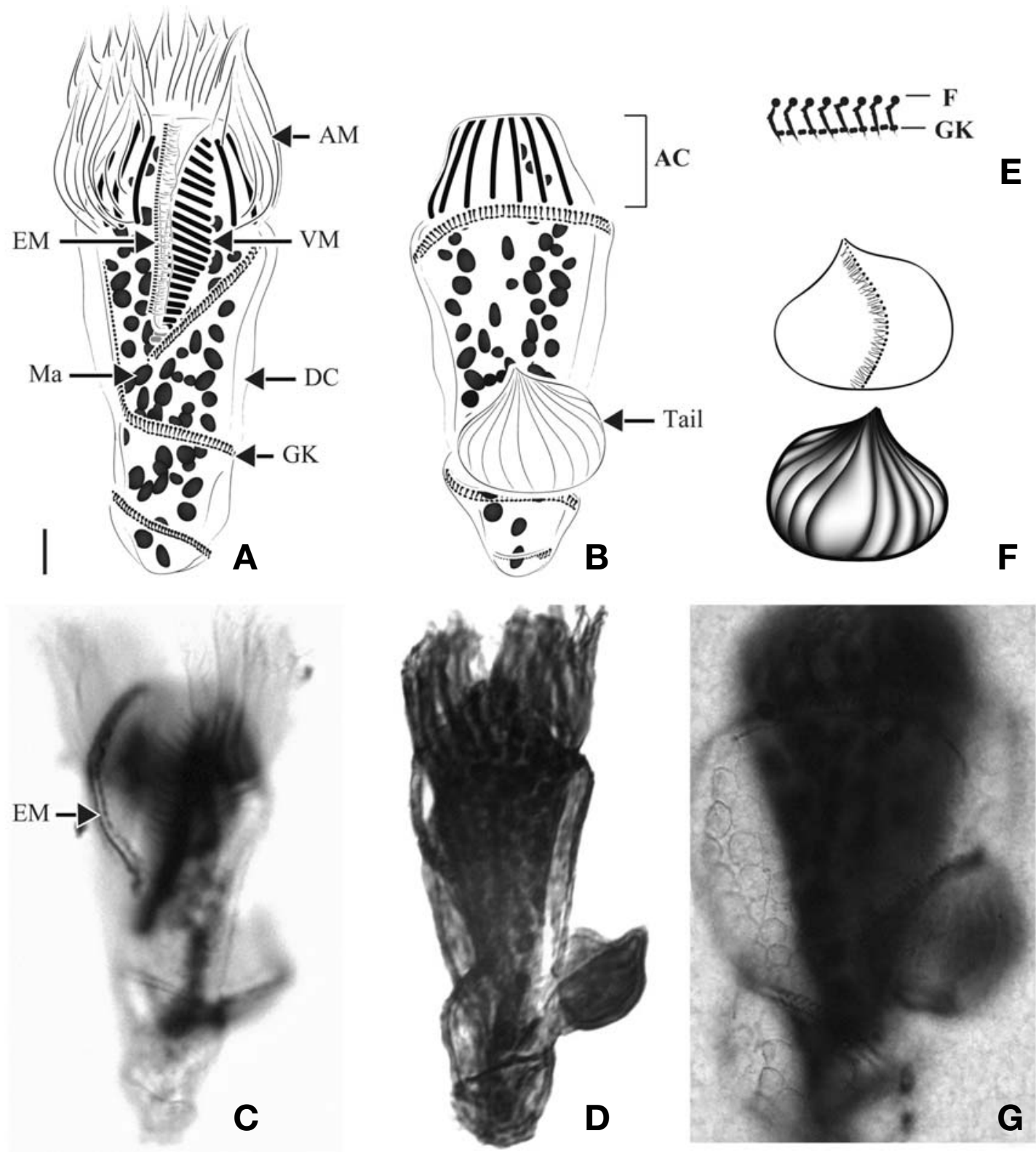

Fig. 8. Spirotontonia grandis after protargol impregnation. A, C, Ventral view; B, Dorsal view; $D$, Left view (B and D show that tail is located on the second whorl GK); $E$, Detail of GK arrangement with $F$ (probably fibers); $F$, Detail of tail appearance, top is the front view and bottom is the back view with wrinkled surface; G, Plated-form on surface of DC. AC, apical collar; F, probably fibers; DC, distended cell surface. Scale bar: $10 \mu \mathrm{m}$. 


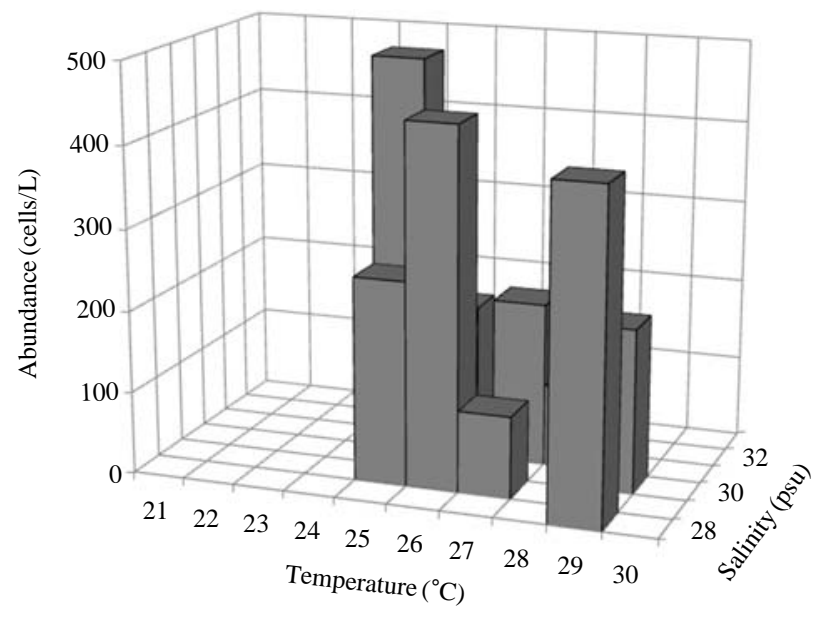

Fig. 9. Abundances of Spirotontonia grandis at different temperatures $\left({ }^{\circ} \mathrm{C}\right.$ ) and salinities (psu) in Masan Bay.

stained (the number of kinetids per $10 \mu \mathrm{m} \mathrm{GK}=15$ and $\mathrm{F}=7$ on average). No VK detected.

Oval or irregular shaped Ma scattered in whole of body, 3-4 $\mu \mathrm{m}$ in diameter (average $3 \mu \mathrm{m}, \mathrm{n}=19$ ), and 37-84 in number (average 65, $\mathrm{n}=19$ ).

Occurence and ecological characteristics. This species were collected from Masan Bay in August 2006-2008 and Jangmok Bay in June 2009. During the survey period, this species was found only in summer at high water temperature $\left(>17^{\circ} \mathrm{C}\right)$. In Jangmok Bay, this species and $S$. turbinata were simultaneously observed at the temperature range of 17.45$23.27^{\circ} \mathrm{C}$ and salinity of 30.30-31.51 psu. Maximum abundance $(1,100$ cells/L) of this species was observed at M27 site in Masan Bay in August 2006 where water temperature of $25.78^{\circ} \mathrm{C}$ and salinity of $29.50 \mathrm{psu}$ were recorded respectively (Fig. 9).

Comparison with other populations. Spirotontonia grandis was recently described as a new species from the East China Sea and the Korea Strait (Suzuki and Han, 2000). This species was also recorded from the Irish Sea (Agatha, 2004c). Water temperature of $14.5-24.9^{\circ} \mathrm{C}$ and salinity of $30.7-34.5$ psu were recorded when Chinese population was collected from the East China Sea in May, 1997 (Suzuki and Han, 2000). European population in the Irish Sea occurred in the hydrological environment of $\sim 12^{\circ} \mathrm{C}$ and salinity of $\sim 35$ psu in May, 2002 (Agatha, 2004c). Compared with Chinese population and Korean population, European population shows larger size (146-189 $\mu \mathrm{m}$ in length of European population vs. $70-155 \mu \mathrm{m}$ in length of Chinese population vs. $87-157.5 \mu \mathrm{m}$ in length of Korean population) and has more $\mathrm{Ma}(82-113$ vs. $55-88$ vs. 37-84). It is assumed that Korean population is more similar to Chinese population than European population. Chinese and European populations were mentioned to have cortical platelets. According to Suzuki and Han (2000), both platedform and aplated-form (lacking the platelets) on surface of DC were found in Chinese population. However, there is no difference of other morphologic characteristics between these two forms. Korean population has also two forms in similar morphology.

\section{ACKNOWLEDGEMENTS}

This study was supported by the grant from the Korean Ocean Research and Development Institute (PE98582), the National Research Foundation of Korea Grant funded by the Korea Government (No. 2009-0077263), and "The Survey of Korean Indigenous Species" supported by the National Institute of Biological Resources (NIBR) of Korea.

\section{REFERENCES}

Agatha S, 2004a. A cladistic approach for the classification of oligotrichid ciliates (Ciliophora: Spirotricha). Acta Protozoologica, 43:201-217.

Agatha S, 2004b. Evolution of ciliary patterns in the Oligotrichida (Ciliophora, Spirotricha) and its taxonomic implications. Zoology, 107:153-168.

Agatha S, 2004c. New observations on the tontoniid ciliate Spirotontonia grandis (Suzuki and Han, 2000) Agatha, 2004 (Ciliophora, Oligotrichida, Tontoniidae); comparison with the similar Laboea strobila. European Journal of Protistology, 40:295-301.

Agatha S, 2011. Updated hypothesis on the evolution of oligotrichid ciliates (Ciliophora, Spirotricha, Oligotrichida) based on somatic ciliary patterns and ontogenetic data. European Journal of Protistology, 47:51-56.

Agatha S, Riedel-Lorjé JC, 1998. Morphology, infraciliature, and ecology of some Strobilidiine ciliates (Ciliophora, Oligotrichea) from coastal brackish water basins of Germany. European Journal of Protistology, 34:10-17.

Agatha S, Strüder-Kypke MC, 2007. Phylogeny of the order Choreotrichida (Ciliophora, Spirotricha, Oligotrichea) as inferred from morphology, ultrastructure, ontogenesis, and SSrRNA gene sequences. European Journal of Protistology, 43:37-63.

Foissner W, Berger H, Schaumburg J, 1999. Identification and ecology of limnetic plankton ciliates. Informationsberichte des Bayerischen Landesamtes für Institut für Wasserwirtschaft, 3/99:1-793.

Froneman PW, Perissinotto R, 1996. Microzooplankton grazing and protozooplankton community structure in the South Atlantic and in the Atlantic sector of the Southern ocean. Deep-Sea Research Part I Oceanographic Research Papers, 43:703-721.

Han GB, Lee WJ, 2010. Temporal variations and species com- 
position of planktonic tintinnids (Protist, Ciliophora) in the Korea Strait. Journal of the Korean Society of Oceanography, 15:176-183.

Jeong HJ, Kim JS, Kim S, Song JY, Lee I, Lee GH, 2004. Strombidinopsis jeokjo n. sp. (Ciliophora: Choreotrichida) from the coastal waters off western Korea: morphology and small subunit ribosomal DNA gene sequence. Journal of Eukaryotic Microbiology, 51:451-455.

Kahl A, 1932. Urtiere oder Protozoa I: Wimpertiere oder Ciliata (Infusoria), 3. Spirotricha. Die Tierwelt Deutschlands, 25: 399-650.

Kim JS, Jeong HJ, Strüeder-Kypke MC, Lynn DH, Kim S, Kim JH, Lee SH, 2005. Parastrombidinopsis shimi n. gen., n. sp. (Ciliophora: Choreotrichia) from the coastal waters of Korea: morphology and small subunit ribosomal DNA sequence. Journal of Eukaryotic Microbiology, 52:514-522.

Kim SY, Yang EJ, Gong J, Choi JK, 2010a. Redescription of Favella ehrenbergii (Claparède and Lachmann, 1858) Jörgensen, 1924 (Ciliophora: Choreotrichia), with phylogenetic analysis based on small subunit rRNA gene sequences. Journal of Eukaryotic Microbiology, 57:460-467.

Kim YH, Lee JB, 2003. Seasonal variations and species composition of planktonic ciliates in the southern coastal waters of Jeju Island, Korea. The Sea, Journal of the Korean Society of Oceanography, 8:59-69.

Kim YO, Ha SY, Taniguchi A, 2008. Morphology and in situ sedimentation of the cysts of a planktonic oligotrich ciliate, Strombidium capitatum. Aquatic Microbial Ecology, 53:173179.

Kim YO, Kim SY, Lee WJ, Choi JK, 2010b. New observations on the choreotrich ciliate Strombidinopsis acuminata FauréFremiet 1924, and comparison with Strombidinopsis jeokjo Jeong et al., 2004. Journal of Eukaryotic Microbiology, 57: 48-55.

Kim YO, Yang EJ, Kang JH, Shin K, Chang M, Myung CS, 2007. Effects of an artificial breakwater on the distributions of planktonic microbial communities. Ocean Science Journal, 42:9-17.

Lee JB, Kim YH, 2010. Distribution of tintinnids (Loricate ciliates) in East Asian waters in summer. Coastal Environmental and Ecosystem Issues of the East China Sea. TERRAPUB and Nagasaki University, Tokyo, pp. 173-180.

Lee KC, Choi JK, Kim SY, Yang EJ, 2006. First record of two marine planktonic ciliates Rimostrombidium orientale and $R$. veniliae (Ciliophora: Choreotrichida) from Korea. Korean Journal of Systematic Zoology, 22:217-221.

Lee WJ, Shin KS, Lee JD, 2007. Studies on marine heterotrophic protists in Masan Bay, Korea. Ocean and Polar Research, 29: 401-410.

Lynn DH, 2008. The ciliated protozoa: characterization, classification, and guide to the literature. 3rd ed. Springer, Dordrecht, pp. 1-606.

Ma H, Choi JK, 2005. Morphogenesis of marine ciliate Pelagostrobilidium (Ciliophora: Oligotrichia). Korean Journal of Systematic Zoology, 21:21-30.
Montagnes DJS, Lynn DH, 1987. A quantitative protargol stain (QPS) for ciliates: method description and test of its quantitative nature. Marine Microbial Food Webs, 2:83-93.

Montagnes DJS, Lynn DH, 1991. Taxonomy of choreotrichs, the major marine planktonic ciliates, with emphasis on the aloricate forms. Marine Microbial Food Webs, 5:59-74.

Moon EY, Kim YO, Kim BH, Kong DS, Han MS, 2004. Taxonomic and ecologic studies on ciliate plankton in Pal'tang reservoir, Korea. Korean Journal of Limnology, 37:149-179.

Ota T, Taniguchi A, 2003. Stanading crop of planktonic ciliates in the East China Sea and their potential grazing impact and contribution to nutrient regeneration. Deep-Sea Research Part II Topical Studies in Oceanography, 50:423-442.

Petz W, Foissner W, 1992. Morphology and morphogenesis of Strobilidium caudatum (Fromentel), Meseres corlissi n. sp., Halteria grandinella (Müller), and Strombidium rehwaldi n. sp., and a proposed phylogenetic system for oligotrich ciliates (Protozoa, Ciliophora). Journal of Eukaryotic Microbiology, 39:159-176.

Quevedo M, Anadón R, 2000. Spring microzooplankton composition, biomass and potential grazing in the central Cantabrian coast (Southern Bay of Biscay). Oceanologica Acta, 23:297-309.

Song W, Bradbury PC, 1998. Studies on some new and rare reported marine planktonic ciliates (Ciliophora: Oligotrichia) from coastal waters in North China. Journal of the Marine Biological Association of the United Kingdom, 78:767-794.

Song W, Warren A, Hu X, 2009. Free-living ciliates in the Bohai and Yellow Seas, China. Science Press, Beijing, pp. 1-518.

Suzuki T, Han MS, 2000. A study on a new species of Tontonia (Ciliophora: Oligotrichida) from the East China Sea and adjacent sea areas. Journal of the Marine Biological Association of the United Kingdom, 80:989-994.

Vaqué D, Blough HA, Duarte CM, 1997. Dynamics of ciliate abundance, biomass and community composition in an oligotrophic coastal environment (NW Mediterranean). Aquatic Microbial Ecology, 12:71-83.

Wilbert N, 1975. Eine verbesserte Technik der Protargolimprägnation für Ciliaten. Mikrokosmos, 6:171-179.

Yang EJ, Choi JK, 2003. The study on the seasonal variation of microbial community in Kyeonggi Bay, Korea II. Nano- and microzooplankton. The Sea, Journal of the Korean Society of Oceanography, 8:78-93.

Yoo HB, Park SS, 2001. Seasonal dynamics and community structure of tintinnina in lower Seomjin river system. Korean Journal of Environmental Biology, 19:25-36.

Yoo KI, Kim YO, 1990. Taxonomical studies on tintinnids (Protozoa: Ciliata) in Korean coastal waters, 2. Yongil Bay. Korean Journal of Systematic Zoology, 6:87-122.

Yoo KI, Kim YO, Kim DY, 1988. Taxonomical studies on tintinnids (Protozoa: Ciliata) in Korean coastal water. 1. Chinhae Bay. Korean Journal of Systematic Zoology, 4:67-90.

Received May 11, 2011 Accepted June 17, 2011 